\title{
A 3D Printed 2×2 Circular Planar Antenna Array for Wireless Communications Applications
}

\author{
Ashraf E. Ahmed ${ }^{1, *}$, Wael A.E. Ali ${ }^{2, \dagger}$, Sudipta Das ${ }^{3, \ddagger}$ \\ ${ }^{1}$ Electronics \& Comm. Engineering Department, College of Engineering, Higher Institute of Engineering and \\ Technology, King Marriott, Alexandria, Egypt \\ ${ }^{2}$ Electronics \& Comm. Engineering Department, College of Engineering, Arab Academy for Science, Technology \\ and Maritime Transport (AASTMT), Alexandria, Egypt \\ ${ }^{3}$ Department of Electronics and Communication Engineering, IMPS College of Engineering and Technology, \\ Malda, WB, India
}

(Received 21 March 2021; revised manuscript received 15 June 2021; published online 25 June 2021)

\begin{abstract}
In this work, a 3D printed $2 \times 2$ circular planar antenna array was designed to explain the usability of 3DP technique for RF systems. An innovative process with etching substrate in PLA dielectric is implemented. The designed planar array antenna consists of four circular antenna elements combined with power divider on the top layer of PLA substrate and the ground plane is mounted on the bottom layer of substrate, both the patch and the ground are made of red copper sheet with a thickness of $1 \mathrm{~mm}$ and an overall size of $133.14 \times 146.5 \times 2 \mathrm{~mm}^{3}$. The proposed array used PLA substrate material with relative permittivity of 3.1 and loss tangent of 0.001 , and all parts of the antenna are fixed by screw nails. The novel circular planar antenna array operates with one input feeding by a coaxial connector connected directly to transmission line, which is merged with the designed power divider, the final power divider consists of two sections combined together and simulated individually to investigate their performance through the reflection coefficient and isolation between ports. The 3D printed circular planar array is simulated and the obtained results, such as $S_{11}$ reached up to $-15.69 \mathrm{~dB}$ at $2.63 \mathrm{GHz}$ and the total gain of $6.73 \mathrm{dBi}$, are obtained at the achieved band, and also other bands are generated which confirms the suitability of the proposed array for various wireless applications.
\end{abstract}

Keywords: 3D printing, PLA, Circular, Planar antenna array.

DOI: 10.21272/jnep.13(3).03028

PACS number: 84.40.Ba

\section{INTRODUCTION}

Antenna array systems are generally used in radar and satellite communication applications for achieving high gain, narrow beam width and multiband operations. The conventional fabrication technique for antenna array structure is usually complicated, need to high-cost materials or high-temperature welding that may be cause a damage in the substrate [1]. Fast fabricating prototype, strong, reliable, and low expansive materials for antenna array are still a challenge. Various array antennas are discussed for wireless applications such as triangular antenna array [2, 3], rectangular-shaped monopole antenna array, C-shaped monopole antenna array [4-8], and so on.

A 3D printing (3DP) or additive manufacturing (AM) has been discussed to be the future of fabrication given its massive effort in revolution both in design and fabrication methods [9]. 3DP permits 3D objects with different geometry shapes to be printed automatically layer by layer, enabling the realization of sophisticated shapes such as 3D conformal shapes [10], more flexible design [11]. In addition, 3D printed systems can benefit from reducing fabrication costs. Thus, 3DP may be a convenient technique to manufacture $\mathrm{RF}$ components and systems [12]. A novel 3DP hybrid technique for fabricating functional $\mathrm{RF}$ systems such as antennas, microstrip at the chamber temperature that maintains good electro-magnetic performance has been explained in [13]. The 3DP technique carried out etching in PLA dielectric substrate to explain the simplicity and applicability of the 3D printing technique for RF system.

A 3 D printed $2 \times 2$ antenna array is used to achieve the desired radiation pattern which cannot be obtained by using a single element. Also, one of the main aims in designing an antenna is to enhance the gain and directivity [14-17]. The elements can be used by a single line or by multiple lines in a power divider network arrangement. So, in this paper we used a circular planar antenna array connected together with a Wilkinson power divider to improve the overall performance. Furthermore, the radiating elements of the circular antenna are distributed symmetrically with respect to the ground plane [18]. The patch antenna and ground plane are made from red copper with thickness of $1 \mathrm{~mm}$, and the dielectric part is printed by 3DP machine using PLA thermoplastic material of thickness $2 \mathrm{~mm}$ to enhance the gain and performance of antenna array $[19,20]$, then all parts are fixed by screw nails accurately. This work is arranged as follows. In part II, design and fabrication procedures based on 3DP technique for various parts of the antenna array are given. In part III, the simulation results of the $3 \mathrm{D}$ printed antenna array system are introduced. In part IV, the conclusion is presented.

\footnotetext{
*aeltyib_ahmd@yahoo.com

†wael.ali@aast.edu

‡ sudipta.das1985@gmail.com

The results were presented at the International Conference on Innovative Research in Renewable Energy Technologies (IRRET-2021)
} 


\section{DESIGN AND FABRICATION PROCEDURE}

The 3D printed $2 \times 2$ planar antenna array operates at $2.4 \mathrm{GHz}$, fed by SMA connector which is welded from the outer conductor with the ground plane and the inner conductor is welded by T.L. (transmission line) which is merged with the designed power divider. The 3DP circular array antenna consisting of four circular antenna elements is connected with the power divider at $45^{\circ}$ and the substrate is etched with multi circular shapes as in [21] to achieve the desired performance.

\subsection{Circular Antenna Element}

As shown in Fig. 1, it can be observed that the circular antenna of a radius of $20.80 \mathrm{~mm}$ with etched substrate (Apollonian gasket) resonates at 2.39, 3.56, 4.7, $5.6,6.12 \mathrm{GHz}$ with input reflection coefficient reached to $-26.6,-15,-21.2,-30.2,-27.6 \mathrm{~dB}$, respectively.

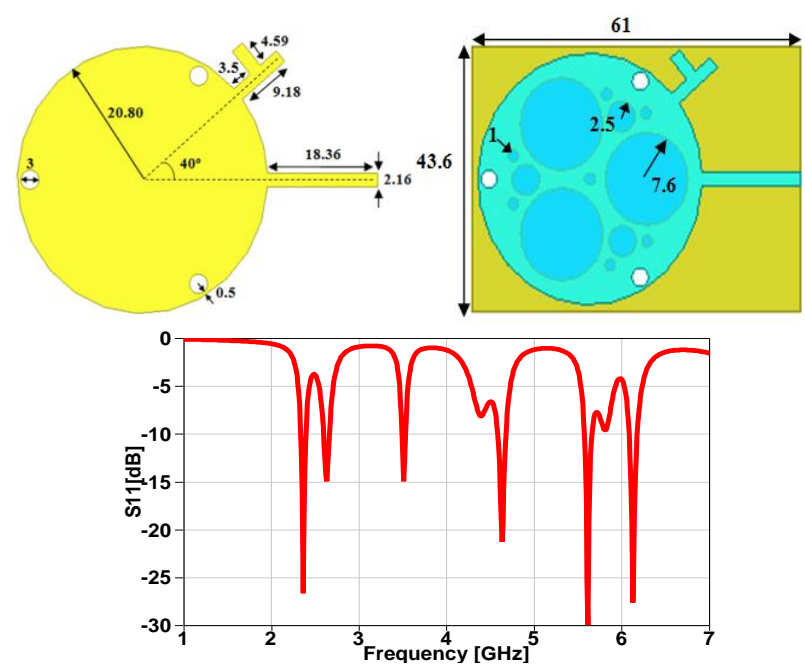

Fig. 1 - The top views and simulated $S_{11}$ result of a circular antenna element with etched multicircular (Apollonian gasket) substrate

\section{$2.2 \quad 1^{\text {st }}$ Power Divider}

The first power divider as shown in Fig. 2 consists of a $\mathrm{T}$ splitter made of copper patch and a ground plane
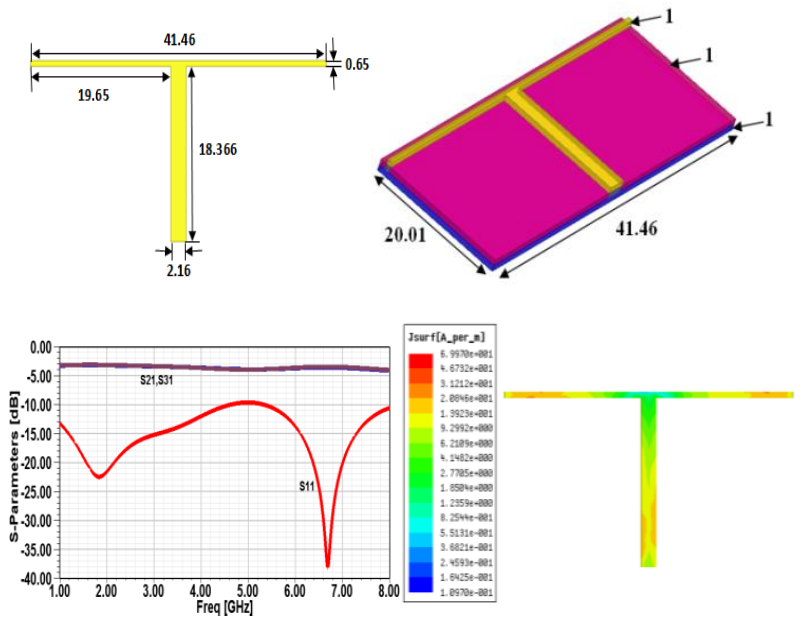

Fig. 2 - The 2D, 3D views, simulated $S$ parameters and current distribution result for the $1^{\text {st }}$ power divider with a thickness of $1 \mathrm{~mm}$, the divider split the input power by equal halves, and it is confirmed from the $S$ parameters and the current distribution of Fig. 2 that the $S_{21}$ and $S_{31}$ are at the same level of approximately $-3 \mathrm{~dB}$ over the achieved band ( $1 \mathrm{GHz}-8 \mathrm{GHz})$.

\section{$2.3 \quad 2^{\text {nd }}$ Power Divider}

As shown in Fig. 3, the second power divider was designed to divide the input power to equal four portions and used it to construct the planar array antenna with one input feeding. It can be observed from Fig. 3 that the power is equally divided between the four ports with the same level of insertion loss, and it is confirmed by the current distribution.

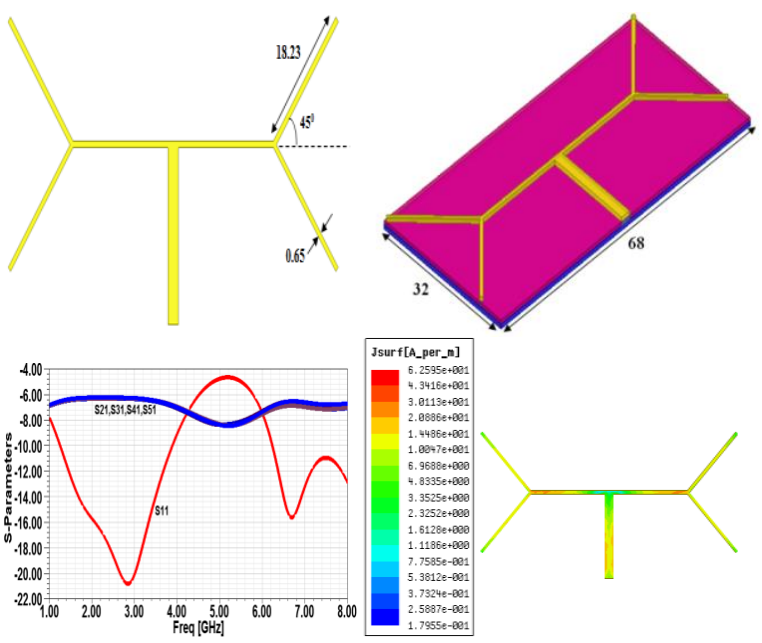

Fig. 3 - The 2D, 3D views, simulated $S$ parameters and current density result for the $2^{\text {nd }}$ power divider

\section{3D PRINTED $2 \times 2$ CIRCULAR ANTENNA ARRAY}

A 3 D printed $2 \times 2$ circular planar array antenna consists of four circular antenna elements combined with final power divider at $45^{\circ}$ and is shown in Fig. 4. The simulations are carried out using high frequency structure simulator (HFSS) software version 13 with a patch and ground plane of a thickness of $1 \mathrm{~mm}$ which are made of red copper and substrate from PLA of $2 \mathrm{~mm}$ thickness.

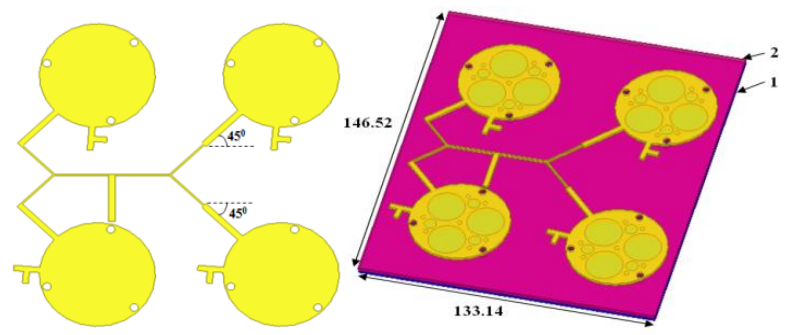

Fig. 4 - The 2D, 3D views for $3 \mathrm{DP}$ etched substrate $2 \times 2$ circular antenna array

The simulation result is indicated in Fig. 5, and it can demonstrate that the proposed 3DP circular etched

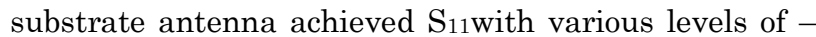
$15.69,-19.69,-19.85,-17.29 \mathrm{~dB}$ at $2.63,4.45,5.75$, $7.89 \mathrm{GHz}$, respectively. The multiband behavior of the suggested antenna makes it a good candidate for various wireless applications [22]. 


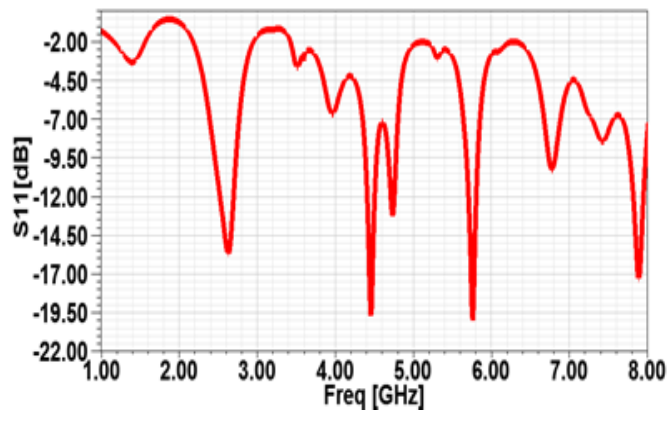

Fig. 5 - The simulated $S_{11}$ parameter result for final 3DP etched $2 \times 2$ circular antenna array

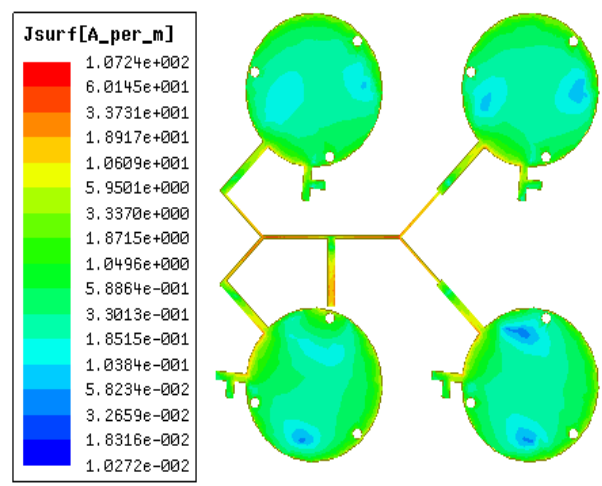

Fig. 6 - Current density for final $3 \mathrm{DP}$ etched substrate $2 \times 2$ circular antenna array at $2.4 \mathrm{GHz}$

Fig. 6 shows a uniform current distribution for the proposed antenna at the WLAN band and presents a uniform medium surface current density at four antenna elements and high distribution at arms, transmission line feeding.

Fig. 7 indicates the $3 \mathrm{D}$ pattern of total gain at the

\section{REFERENCES}

1. U. Ullah, N. Mahyuddin, Z. Arifin, IEEE Anten. Propag. Magaz. 57, 241 (2015).

2. Zaakari Saf, Zenkour Lahbib, J. Microwave, Optoelectron. Electromag. Appl. 12 No 1, 23 (2013).

3. C. Aissaoui, A. Benghalia, J. Microwave., Optoelectron. Electromag. Appl. 16, 1 (2017).

4. M. Farran, D. Modotto, V. Ferrari, Electron. Lett. 15, 918 (2015).

5. Xu Bao Sun, Mao Yong Cao, IEEE Electron. Lett. 53 No 6, 368 (2017)

6. Y.M. Madany, D.A.E. Mohamed, W.A.E. Ali, H.A. Abd-Alnaeem, 2016 UKSim-AMSS 18th International Conference on Computer Modelling and Simulation (UKSim), Cambridge, 325 (2016).

7. D.A.E. Mohamed, W.A.E. Ali, H.A. Abd-Alnaeem, Y.M. Madany, 2016 17th International Symposium on Antenna Technology and Applied Electromagnetics (ANTEM) (Montreal, QC: 2016).

8. Y.M. Madany, D.A.E. Mohamed, W.A.E. Ali, R.F. Emara, 2017 UKSim-AMSS 19th International Conference on Computer Modelling \& Simulation (UKSim), 235 (Cambridge: 2017).

9. History of $3 D$ Printing: When was $3 D$ Printing Invented? All3DP. (2018).

10. P. Nayeri, M. Liang, R.A. Sabory-Garc, IEEE Trans. Anten. Propag. 62 No 4, 2000 (2014).

11. M. Mirzaee, L. Wiest, IEEE International Symposium on Antennas and Propag. \& USNC/URSI National Radio Science Meeting (2015). same band for 3 DP $2 \times 2$ circular etched antenna array, the achieved gain is $6.73 \mathrm{dBi}$ with a directional property along the $z$-axis, it is worth noting that the antenna array is constructed in the $x-y$ plane, and the total gain and current distribution are simulated at $2.4 \mathrm{GHz}$.

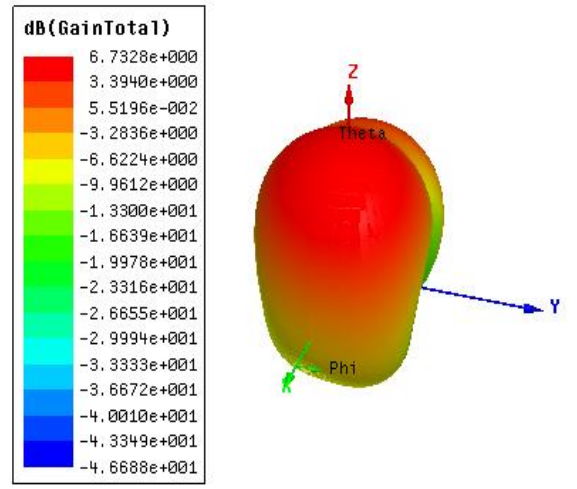

Fig. 7 - The simulated total gain for 3DP etched substrate planar antenna array at $2.4 \mathrm{GHz}$

\section{CONCLUSIONS}

In this paper, a four circular element antenna array printed over an etched PLA substrate is designed, implemented, and simulated for wireless applications. The functional properties of the proposed $2 \times 2$ circular array, are mainly reflection coefficient $S_{11}$ and gain have been carried out to investigate the desired performance. The proposed array antenna is achieved a return loss of $-15.69 \mathrm{~dB}$ at $2.63 \mathrm{GHz}$ with a gain reached to $6.73 \mathrm{dBi}$. The entire size of the suggested $3 \mathrm{DP}$ circular antenna array was $133.14 \times 146.5 \times 2 \mathrm{~mm}^{3}$. Consequently, the suggested antenna array could be used for various wireless communication applications.

12. 3-D Printing Steps into the Spotlight. Upstate Business Journal. 11 April 2013. Retrieved 20 December 2019.

13. M. Liang, X. Yu, C. Shemelya, E. MacDonald, H. Xin, IEEE MTT-S Intl Microwave Symp. (IMS) (2015).

14. W.A.E. Ali, Ehab K.I. Hamad IEEE Int. Conf. on Innovative Trends in Computer Engineering (ITCE'2018), 197 (Aswan, Egypt: 2018).

15. W.A. Ali, A.I. Zaki, M.H. Abdou, Microwave Opt. Technol. Lett. 58, 2268 (2016).

16. W.A.E. Ali, H.A. Mohamed, A.A. Ibrahim, M.Z.M. Hamdalla, Microsyst. Technol. 25 No 1, 4111 (2019).

17. Soufian Lakrit, Hicham Medkour, Sudipta Das, B.T.P. Madhav, Wael A.E. Ali, R.P. Dwivedi, Appl. J. Circ., System. Comput. 1 (2020).

18. T.P. Ketterl, Y. Vega, N.C. Arnal, IEEE Trans. Microwave Theory Tech. 63 No 12, 4382 (2015).

19. B. Ramya, C. Supratha ICTACT J. Microelectron. 03 No 4, 457 (2018).

20. X. Yu, M. Liang, C. Shemelya, D.A. Roberson, R. Wicker, IEEE Anten. Wireless Propag. Lett. 17 No 11, 2150 (2018).

21. A.E. Ahmed, W.A.E. Ali, International Conference on Electrical, Communication and Computer Engineering (ICECCE) (Istanbul, Turkey: 2020).

22. A.E. Ahmed, W.A.E. Ali, International Conference on Electrical, Communication, and Computer Engineering (ICECCE) (Istanbul, Turkey: 2020). 


\title{
Надрукована на 3D принтері кругла плоска антенна решітка $2 \times 2$ для додатків бездротового зв'язку
}

\author{
Ashraf E. Ahmed ${ }^{1}$, Wael A.E. Ali², Sudipta Das ${ }^{3}$ \\ ${ }^{1}$ Electronics \& Comm. Engineering Department, College of Engineering, Higher Institute of Engineering and \\ Technology, King Marriott, Alexandria, Egypt \\ ${ }^{2}$ Electronics \& Comm. Engineering Department, College of Engineering, Arab Academy for Science, Technology \\ and Maritime Transport (AASTMT), Alexandria, Egypt \\ ${ }^{3}$ Department of Electronics and Communication Engineering, IMPS College of Engineering and Technology,
} Malda, WB, India

\begin{abstract}
$\mathrm{Y}$ роботі була розроблена кругла плоска антенна решітка $2 \times 2$, надрукована на 3D принтері, для пояснення зручності використання технології 3DP для радіочастотних систем. Впроваджено інноваційний процес з травленням підкладки в діелектрику PLA. Спроектована плоска антенна решітка складаеться з чотирьох круглих антенних елементів у поеднанні з дільником потужності на верхньому шарі підкладки з PLA, а заземлювач встановлюеться на нижньому шарі підкладки. I патч, і заземлювач виготовлені з червоного мідного листа товщиною 1 мм і загальним розміром $133,14 \times 146,5 \times 2$ мм³ $^{3}$ У запропонованій антенній решітці використовували матеріал підкладки PLA 3 відносною діелектричною проникністю 3,1 і тангенсом кута втрат 0,001 , а всі частини антени закріплювали гвинтовими цвяхами. Нова кругла плоска антенна решітка працюе з одним входом, який живиться від коаксіального роз'єму, підключеного безпосередньо до лінії електропередачі, яка об'єднана з розробленим дільником потужності. Кінцевий дільник потужності складаеться з двох секцій, об'єднаних разом і змодельованих індивідуально для дослідження їх характеристик через коефіціент відбиття та ізоляцію між портами. Змодельовано круглу плоску антенну решітку, надруковану на 3D принтері, і отримано результати, такі як $S_{11}$, що сягае до - 15,69 дБ на частоті 2,63 ГГц, загальний коефіщіент підсилення 6,73 дБі, у досягнутому діапазоні; також генеруються інші смуги, що підтверджуе придатність запропонованої антенної решітки для різних бездротових додатків.
\end{abstract}

Ключові слова: 3D друк, PLA, Круглий, Плоска антенна решітка. 